\title{
Failure to detect altered rosette inhibition titres in human pregnancy serum
}

\author{
D. W. Cooper* and R. J. Aitken \\ M.R.C. Unit of Reproductive Biology, Centre of Reproductive Biology, 37 Chalmers Street, \\ Edinburgh EH3 9EW, U.K.
}

\begin{abstract}
Summary. Six anti-lymphocyte antisera and 6 anti-lymphocyte globulin preparations were tested on serum from women in the first and second trimester of pregnancy and on appropriate sera from non-pregnant controls. There were no differences and the results do not confirm the claim that the serum of pregnant women contains a factor that will prevent human lymphocytes forming spontaneous rosettes with sheep red blood cells, and that this serum factor makes its appearance early in pregnancy.
\end{abstract}

\section{Introduction}

Morton, Rolfe, Clunie, Anderson \& Morrison (1977) used the rosette inhibition test (RIT) to detect early pregnancy in women. They found that a goat antiserum to neonatal human thymocytes would inhibit rosette formation by human lymphocytes with sheep red blood cells at higher dilutions if the lymphocytes were taken from pregnant as opposed to non-pregnant women. The dilution at which this occurred was the basis of the RIT. The factor responsible was thought to be in the serum because when lymphocytes from non-pregnant women or from men were incubated in serum from pregnant women a higher RIT was exhibited than for buffer-incubated controls. In the first two trimesters there was very little overlap between the titres of pregnant and non-pregnant women. Morton et al. (1977) called the factor early pregnancy factor (EPF) and proposed that it had immunosuppressive properties necessary for the continued viability of the early embryo. We report here our attempts to detect differences in rosette inhibition titre in the serum of pregnant women compared to the sera of non-pregnant women and men.

\section{Materials and Methods}

Blood was obtained from 34 pregnant women, 11 in the first trimester, 9 in the second and 14 in the third. Ten non-pregnant women and 7 men were bled as controls. Sera were stored frozen at $-20^{\circ} \mathrm{C}$ until tested.

Carrier lymphocytes were isolated from $25-30 \mathrm{ml}$ of blood from non-pregnant women or men, by using Lymphoprep (Nyegaard, Oslo) as described by Böyum (1964), washed 3 times

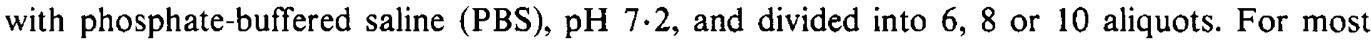
experiments, half of the aliquots of carrier lymphocytes were incubated at $37^{\circ} \mathrm{C}$ with a 1 in 2 dilution of sera from pregnant women and the other half with serum from non-pregnant control

* Present address: School of Biological Sciences, Macquarie University, North Ryde, New South Wales 2113 , Australia.

$0022-4251 / 81 / 010241-05 \$ 02.00 / 0$

(C) 1981 Journals of Reproduction \& Fertility Ltd 
individuals. The lymphocytes were then washed twice in PBS or Hanks' balanced salt solution and their rosette inhibition titre determined as described by Morton et al. (1977). The one significant departure from their protocol (see Text-fig. 1) was that we did not determine the titre for cells incubated in balanced salt solution alone, which Morton et al. (1977) took as their basal control value. In our study the control incubations contained the same population of lymphocytes incubated in non-pregnant female or male serum.

An antiserum to human chorionic villi of 6-8 weeks of gestation was made by injecting a rabbit intradermally with an homogenate of chorionic tissue ( 1 part chorionic tissue: 3 parts balanced salt solution, w/v) on 4 occasions at 2-week intervals and bleeding 2 weeks after the last injection. Each injection contained $0.2 \mathrm{ml}$ homogenate in $0.8 \mathrm{ml}$ Freund's complete adjuvant. Antisera to serum and peripheral lymphocytes from pregnant women were prepared in rabbits by a similar procedure. Each injection of serum contained $0.8 \mathrm{ml}$ Freund's complete adjuvant and $0.2 \mathrm{ml}$ of a pool of equal quantities of serum from 10 pregnant women ( 2 from the first trimester, 2 from the second and 6 from the third). From $3 \times 10^{6}$ to $3 \times 10^{7}$ white cells were injected in $0.5 \mathrm{ml}$ balanced salt solution without adjuvant. The sources of the other antisera used and adsorptions performed are indicated in Table 1. With the exceptions noted in Table 1, all experiments on pregnancy sera and pregnancy cells were carried out on first and second trimester samples. The anti-lymphocyte globulin samples were obtained from $\mathrm{Dr} \mathrm{K}$. James. Their IgG concentration ranged from 1.7 to $3.0 \mathrm{~g} / 100 \mathrm{ml}$.

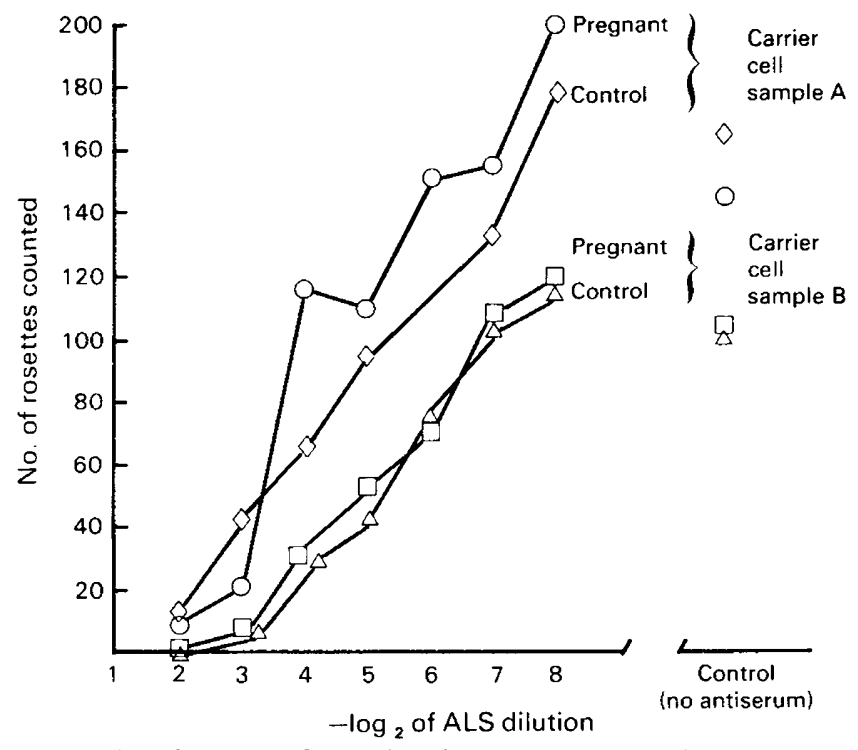

Text-fig. 1. An example of rosette formation in the presence of various quantities of antilymphocyte serum (ALS) by 2 separate populations of lymphocytes (carrier cells $A$ and $B$ ) incubated with serum from pregnant $(O$ and $\square)$ and non-pregnant control $(\diamond$ and $\triangle)$ individuals. A $1 / 1000$ dilution of antiserum (ALS from Dr K. James) was serially diluted $1 / 4(-\log 2=2)$ to $1 / 256(-\log 2=8)$. Two aliquots of the same sample of carrier lymphocytes were incubated with two different pregnancy sera and two with 2 different non-pregnancy sera for 30 min at $37^{\circ} \mathrm{C}$ and then washed with PBS (see text). To $50 \mu$ l of each dilution of ALS were added $50 \mu \mathrm{l}$ lymphocyte suspension $\left(5 \times 10^{6}\right.$ cells $\left.\mathrm{ml}^{-1}\right)$ and $50 \mu \mathrm{l}$ of a $1 / 5$ dilution of guinea-pig serum absorbed with human and sheep red blood cells, and this mixture was incubated at $37^{\circ} \mathrm{C}$ for $1.5 \mathrm{~h}$. Then $50 \mu \mathrm{l}$ of a $1 \%$ suspension of sheep red blood cells were added and immediately centrifuged at $1000 \mathrm{~g}$ for $2-3 \mathrm{~min}$. The tubes were stored overnight at $4^{\circ} \mathrm{C}$ and the following morning gently re-suspended and the number of rosettes counted in a haemocytometer (total volume $=9 \times 10^{-4} \mathrm{ml}$ ). Each point on the graph represents the mean value for 2 pregnancy or 2 non-pregnancy sera. 
The number of rosettes in a tube was judged to be significantly diminished if it differed from the control value to the extent that $\chi^{2}$ test on a $1: 1$ comparison gave a value significant at the $5 \%$ level.

\section{Results}

Preliminary tests revealed that $4-45 \%$ of lymphocytes would form rosettes, depending upon the source of sheep red blood cells used, and that neither complement nor antiserum to sheep RBCs were necessary for rosette formation. The rosettes under study are presumably E-rosettes, which are formed by T lymphocytes (reviewed by Chess \& Schlossman, 1977).

Examples of rosette inhibition curves are shown in Text-fig. 1. In agreement with Morton et al. (1977; their Fig. 1), we found that for strong antisera (RIT 1/1000), 6-8 two-fold dilution steps separated the anti-lymphocyte serum titre for complete inhibition (no rosettes) and the titre at which the number of rosettes approximated the control value. For weaker antisera, the range was 2-4 steps. However, unlike Morton et al. (1977), we found that the responses for cells incubated in pregnancy sera were similar to those for cells incubated in non-pregnancy sera. The absolute values for numbers of rosettes at a particular titre varied considerably between different carrier cells (Text-fig. 1), as they did between experiments, although the RIT obtained was reproducible to within a 2 -fold dilution step.

The maximum titre for significant inhibition of rosette formation is shown in Table 1 . In all tests there was considerable overlap between pregnancy and non-pregnancy sera and between pregnancy and non-pregnancy lymphocytes (Exps 1 and 6 in Table 1). No indication of a large difference in titre between the two groups was obtained for any antiserum or anti-

Table 1. Rosette inhibition titre of various antisera for erythrocyte rosette formation by carrier cells coated with human pregnancy or non-pregnancy sera

\begin{tabular}{|c|c|c|c|c|c|c|c|}
\hline \multirow[b]{2}{*}{ Exp. } & \multirow{2}{*}{$\begin{array}{l}\text { Antiserum or } \\
\text { anti-lymphocyte } \\
\text { globulin (ALG) }\end{array}$} & \multirow{2}{*}{$\begin{array}{l}\text { No. of } \\
\text { exps }\end{array}$} & \multirow{2}{*}{$\begin{array}{l}\text { Absorption } \\
\text { procedurest+ }\end{array}$} & \multicolumn{2}{|c|}{ No. of samples tested } & \multicolumn{2}{|c|}{ Inverse of inhibition titres } \\
\hline & & & & Non-pregnancy & Pregnancy & Non-pregnancy & Pregnancy \\
\hline 2 & ALS (James) & 1 & $\begin{array}{l}\text { 1/10 antiserum } 1: 1 \text { with } \\
\text { SRBC }\end{array}$ & 3 & 3 & 3200 & 3200 \\
\hline 3 & ALS (James) & 2 & None & 5 & 9 & $800-6400$ & $1600-6400$ \\
\hline 5 & ALG 29 (James) & 1 & HRBCS & 3 & 3 & 400 & 400 \\
\hline $6^{*+}$ & ALG 29 (James) & 2 & HRBCS & 3 & $14 \ddagger$ & $250-1000$ & $250-2000$ \\
\hline $7+$ & $\begin{array}{l}\text { Antiserum to early } \\
\text { human trophoblast } \\
\text { (6-10 weeks } \\
\text { gestation) }\end{array}$ & 1 & $\begin{array}{l}\text { t antiserum } 1: 1 \text { with } S R B C \text {, } \\
1: 1 \text { with } \mathrm{HRBC} \text {, and } \\
10: 1 \text { with lymphocytes } \\
\text { from non-pregnant } \\
\text { individuals }\end{array}$ & 4 & 6 & $32-64$ & $16-64$ \\
\hline 8 & $\begin{array}{l}\text { Antiserum to lympho- } \\
\text { cytes from pregnant } \\
\text { women }\end{array}$ & 1 & $\begin{array}{l}\text { 1/10 antiserum } 1: 1 \text { with } \\
\text { SRBC }(2 \times), 1: 1 \text { with } \\
\text { HRBC }(2 \times) \text { and } 10: 1 \\
\text { with lymphocytes from } \\
\text { non-pregnant individuals }\end{array}$ & 4 & 4 & $20-320$ & $40-160$ \\
\hline $9+$ & $\begin{array}{l}\text { Antiserum to serum } \\
\text { from pregnant women }\end{array}$ & 1 & $\begin{array}{l}\frac{1}{2} \text { antiserum } 1: 1 \text { with SRBC } \\
(2 \times)\end{array}$ & 4 & 6 & $<2$ & $<2$ \\
\hline 10 & ALG 22 (James) & 1 & HRBCS & 3 & 3 & 1600 & 1600 \\
\hline 11 & ALG 25 (James) & 1 & HRBCS & 3 & 3 & 100 & 100 \\
\hline 12 & ALG 26 (James) & 1 & HRBCS & 4 & 4 & $2560-10240$ & 2560 \\
\hline 13 & ALG 27 (James) & 1 & HRBCS & 3 & 3 & $1600-25600$ & $6400-25600$ \\
\hline 14 & Anti-SPI (Dakopatts) & 1 & None & 3 & 3 & $<4$ & $<4$ \\
\hline $15^{c}$ & ALG 28 & 3 & HRBCS & 6 & 6 & $>3200$ & $>3200$ \\
\hline
\end{tabular}

* Tests performed on cells from non-pregnant and pregnant individuals.

† Some dilutions of antisera had significantly more rosettes than control values (see text).

$\ddagger$ Includes 8 third-trimester samples.

Four-fold dilution steps used.

Andividual difference in shape of first part of inhibition curve. At 1/3200 all samples showed $20-80 \%$ of control value (see text).

** The ALG samples were from 4 separate horses: ALG 22, 25 and 29 were derived from different horses, and ALG 26,27 and 28 were different bleeds from the same horse. All James antisera were raised against peripheral lymphocytes.

$++\mathrm{SRBC}=$ sheep red blood cells; HRBC $=$ human red blood cells; HRBCS = human red blood cell stroma. 
lymphocyte globulin preparation. In several experiments it was noticed that for some combinations of lymphocytes and coating sera the number of rosettes in higher dilutions of antiserum were as much as 2-3 times higher than those for the controls, i.e. small amounts of antiserum were promoting rather than inhibiting rosette formation (see Exps 6, 7, and 9, Table 1). The number of antisera which could give this effect may be greater than indicated in Table 1. because for most of the remaining antisera counts were made starting at the lowest dilution until values near the control were obtained, and tubes beyond this dilution were not counted. Since the effect could be obtained with antisera adsorbed with sheep RBCs, it is unlikely that EAC rosettes (erythrocytes coated with anti-sheep $\mathrm{RBC} \operatorname{IgM}$ and complement) involving $B$ lymphocytes could account for it.

Some antisera possessed haemolysins and/or agglutinins for sheep RBCs (Exps 1, 7,8 and 9. Table 1). Accordingly, adsorption with sheep RBCs was carried out to remove those antibodies and so to prevent formation of $\operatorname{IgM}$ and complement-coated erythrocyte rosettes. To test whether a pregnancy-specific component of lymphocytes was present, two antisera (Exps 7 and 8 , Table 1) were also absorbed with human red cells and lymphocytes. Absorption with the latter was limited because of the difficulty of isolating them in sufficient quantities. The anti-lymphocyte globulin samples obtained from Dr K. James had already been absorbed with human red cell stroma or, for ALG 22, with platelets and stroma.

ALG 28 inhibited cells coated with some sera when used at low dilutions $(1 / 400-1 / 1600)$ much more strongly than it did for cells coated with other sera (Exp. 15, Table 1). A factor present in some sera but not others was apparently affecting rosette formation. Presence or absence of this putative factor was not related to pregnancy.

\section{Discussion}

We have been unable to find any significant difference in the RIT for lymphocytes coated with pregnancy sera and those coated with non-pregnancy sera or between lymphocytes from pregnant and non-pregnant individuals. One possible explanation for these failures is that all of the antisera we used lacked a pregnancy-specific antibody, which was presumably present in the goat anti-human neonatal thymocyte antiserum used by Morton et al. (1977). If this explanation is correct, it means that neonatal thymocytes must possess an antigen which also occurs in pregnancy serum and coats peripheral lymphocytes. We know of no evidence for a shared antigen of this kind.

All of our comparisons between pregnancy and non-pregnancy sera were direct ones, made within the one series of experiments and using the same population of carrier lymphocytes for serum samples from pregnant and non-pregnant women. In the work on man (Morton et al., 1977) and sheep (Morton, Nancarrow, Scaramuzzi, Evison \& Clunie, 1979; Nancarrow, Evison, Scaramuzzi \& Turnbull, 1979) an indirect comparison was used: the RIT for lymphocytes incubated in pregnancy sera was compared with that for the same cells incubated in balanced salt solution after showing in separate experiments that there is no apparent difference in RIT for lymphocytes incubated in non-pregnancy serum or balanced salt solution. The balanced sait solution may not be the best control since the apparent specific effect of pregnancy may be a non-specific effect of all sera. The incorporation of a non-pregnancy serum control, as in the present study, seems essential.

The rosette inhibition test performed in our laboratory also differed from that described by Morton et al. (1977) in that the incubation mixtures were maintained at $4^{\circ} \mathrm{C}$ overnight before counting instead of being counted immediately. The data presented in Table 2 indicate that the rosette inhibition test was not capable of distinguishing between pregnancy or nonpregnancy serum samples regardless of whether the rosettes were counted immediately or after overnight incubation. Overnight incubation did, however, result in an increase in the number of rosettes formed and the RIT; this is presumably because the rapidly formed 'active' rosettes involve a sub-population of $\mathrm{T}$ cells whereas the rosettes formed after overnight incubation incorporate the total T-cell population (Felsburg, Edelman \& Gilman, 1976).com at 04/26/2023 01:36:41PM 
Table 2. RIT for pregnant and non-pregnant serum samples before and after overnight incubation at $4^{\circ} \mathrm{C}$

\begin{tabular}{|c|c|c|c|c|}
\hline \multirow[b]{3}{*}{ Antiserum } & \multicolumn{4}{|c|}{ Rosette inhibition titre } \\
\hline & \multicolumn{2}{|c|}{ Control serum } & \multicolumn{2}{|c|}{ Pregnancy serum } \\
\hline & Immediate counting & Overnight incubation & Immediate counting & Overnight incubation \\
\hline James 22 & $2.5 \times 10^{-3}$ & $2.8 \times 10^{-3}$ & ${ }^{*} 1.4 \times 10^{-3}$ & $2.7 \times 10^{-3}$ \\
\hline James 26 & $4.4 \times 10^{-3}$ & $1.5 \times 10^{-4}$ & $+2.7 \times 10^{-3}$ & $4.6 \times 10^{-3}$ \\
\hline James 26 & $1.4 \times 10^{-3}$ & $6.0 \times 10^{-3}$ & $\ddagger 1.5 \times 10^{-3}$ & $8.0 \times 10^{-3}$ \\
\hline
\end{tabular}

\footnotetext{
* Serum sample taken during 24th week of pregnancy.

+ Serum sample taken during 9 th week of pregnancy.

$\mp$ Serum sample taken during 6th week of pregnancy.
}

One final aspect of the rosette inhibition test which should be considered is the conventional use of a $25 \%$ reduction in the percentage of rosettes formed as the criterion for estimating the RIT. Clearly a cut-off value has to be established at some point but the danger of such a procedure is illustrated in Text-fig. 1 of the paper by Morton et al. (1979). In this figure a change in the criterion for the RIT to a $20 \%$ reduction in the percentage of rosettes formed would bring the RIT for a non-pregnant serum sample into the 'pregnant' range.

Implicit in the studies of Morton et al. (1977) is the assumption that the mother's immunological system is subject to immunosuppression in pregnancy, thereby allowing her to accept the foreign, paternally derived antigens of her conceptus. This hypothesis is superficially appealing and has stimulated many searches for such an effect. However, as Beer (1978) cmphasizes, the mother's humoral and cell-mediated immunity must be fully functional during pregnancy. since the human female is as capable of rejecting foreign antigens when pregnant as she is at any other time in her fertile years. The sole exception to this is the syncytial trophoblast, which seems to be an immunologically privileged tissue, thereby preventing immunological rejection of the conceptus. While it is possible that there are also some serum factors peculiar to pregnancy which interact with maternal lymphocytes, caution should be exercised before ascribing generalized immunosuppressive properties to them. If there are immunosuppressive agents operating in pregnancy, it is more likely that they would interact only with those lymphocytes that would otherwise attack syncytial trophoblast.

We thank Professor D. T. Baird, Dr P. W. Howie, Mr M. Hulme, Dr J. Kerin, Dr A. E. Robertson, Dr S. Smith, Dr J. M. Steele, Sister M. M. Gresham and Mr D. Doogan for their assistance and Dr K. James for the materials indicated in Table 1.

\section{References}

Beer. A. (1978) Possible immunological basis of preeclampsia/eclampsia. Seminars in Perinatology 2, 39-59.

Böyum, A. (1964) Separation of white blood cells. Nature, Lond. 204, 793.

Chess, L. \& Schlossman, S.F. (1977) Human lymphocyte subpopulations. Adv. Immunol. 25, 213-241.

Felsburg, P.J., Edelman. R. \& Gilman, R.H. (1976) The active $\mathrm{E}$ rosette test; correlation with delayed cutaneous hypersensitivity. J. Immunol. I16, $1110-1114$.

Morton. H., Rolfe, B., Clunie, G.J.A.. Anderson. J. \&
Morrison, J. (1977) An early human pregnancy factor detected in human serum by the rosette inhibition test. Lancet i, 394-397.

Morton, H., Nancarrow, C.D., Scaramuzzi, R.J., Evison. B.M. \& Clunie, G.J.A. (1979) Detection of early pregnancy in sheep by the rosette inhibition test. J. Reprod. Fert. 56, 75-80.

Nancarrow, C.D., Evison, B.M., Scaramuzzi, R.J. \& Turnbull, K.E. (1979) Detection of induced death of embryo in sheep by the rosette inhibition test. J. Reprod. Fert. 57, 385-389. 